\title{
Translation and content validation of the Geriatric Institutional Assessment Profile for Brazil
}

\author{
Tradução e validação de conteúdo do Geriatric Institutional Assessment Profile para Brasil \\ La adaptación y validez de contenido a Brasil del Geriatric Institutional Assessment Profile
}

Magda Carla de Oliveira Souza e Silva'

ORCID: 0000-0002-0914-9261

Cinara Maria Feitosa Beleza'

ORCID: 0000-0001-6523-149X

Sônia Maria Soares'

ORCID: 0000-0003-3161-717X

\section{ABSTRACT}

Objective: to describe the process of content adaptation and validation of the Geriatric Institutional Assessment Profile (GIAP) for nurses working in the health care for older adults in Brazilian hospitals. Method: methodological study conducted in five stages: initial translation, synthesis of initial translation, back translation, evaluation by committee of judges, and pre-test for cultural adaptation of the instrument. Results: the instrument evaluation had good agreement between the judges, with general content validity of 0.94 . The items of the translated version evaluated as unsatisfactory by the judges were reformulated from the professionals' considerations in each group. Thirty-one subjects participated in the study. They considered the instrument easy-tounderstand and suggested minor adjustments in some items. Conclusion: the content of the Brazilian version of the GIAP is considered adapted and validated, with potential use in hospital institutions. The next stage will be to submit the instrument to the evaluation process of its psychometric properties for use in Brazilian populations.

'Universidade Federal de Minas Gerais. Belo Horizonte, Minas Gerais, Brazil.

How to cite this article: Silva MCOS, Beleza CMF, Soares SM. Translation and content validation of the Geriatric Institutional Assessment Profile for Brazil. Rev Bras Enferm. 2019;72(Suppl 2):205-13. doi: http://dx.doi.org/10.1590/0034-7167-2018-0602

\section{Corresponding Author: \\ Cinara Maria Feitosa Beleza \\ E-mail: cinara.maria@hotmail.com}

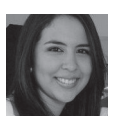

Submission: $03-27-2018$
Approval: 09-23-2018

\section{RESUMO}

Objetivo: descrever o processo de adaptação e validação de conteúdo do Geriatric Institutional Assessment Profile (GIAP) para enfermeiros que atuam no cuidado ao idoso em hospitais brasileiros. Método: estudo metodológico realizado em cinco etapas: tradução inicial, síntese da tradução inicial, retrotradução, avaliação pelo comitê de juízes e préteste para adaptação cultural do instrumento. Resultados: A avaliação do instrumento apresentou boa concordância entre os juízes, com validade de conteúdo geral de 0,94. Os itens da versão traduzida avaliados como insatisfatórios pelos juízes foram reformulados com base nas ponderações dos profissionais de cada grupo. Participaram do pré-teste 31 sujeitos que consideraram o instrumento de fácil compreensão e sugeriram pequenas adequações em alguns itens. Conclusão: Considera-se adaptado e validado o conteúdo do GIAP para a versão brasileira, com potencial utilização em instituições hospitalares. O próximo passo será submeter o instrumento ao processo de avaliação de suas propriedades psicométricas para uso em populações brasileiras.

Descritores: Tradução; Estudos de Validação; Idoso; Enfermagem; Comparação Transcultural.

\section{RESUMEN}

Objetivo: describir el proceso de adaptación y validez de contenido del Geriatric Institutional Assessment Profile (GIAP) a enfermeros que trabajan con el cuidado de adultos mayores en los hospitales de Brasil. Método: estudio metodológico llevado a cabo en cinco etapas: traducción inicial, resumen de la traducción inicial, retraducción, evaluación por el comité de expertos y preprueba a la adaptación cultural del instrumento. Resultados: La evaluación del instrumento mostró buena concordancia entre los jueces, con validación de contenido general de 0,94. Los ítems de la versión traducida y evaluada considerados insatisfactorios por los jueces fueron reformulados desde las ponderaciones de los profesionales de cada grupo. De la preprueba participaron 31 sujetos quienes consideraron el instrumento de fácil comprensibilidad y sugirieron algunos ajustes en ciertos ítems. Conclusión: Se considera adaptado y validado el contenido de GIAP a la versión brasileña, con un potencial uso en los hospitales. El siguiente paso será evaluar las propiedades psicométricas del instrumento para utilizarlo con poblaciones brasileñas.

Descriptores: Traducción; Estudios de Validación; Anciano; Enfermería; Comparación Transcultural. 


\section{INTRODUCTION}

Older adults represent the highest demand for health services, a reality that tends to be intensified due to the increase in longevity, with more frequent and longer hospitalizations compared to the young population. The annual prevalence of hospitalizations of this age group varies between countries: $10 \%$ in Japan, 14\% in the United Kingdom, 16\% in Germany, and 18\% in the United States and Canada ${ }^{(1)}$. In Brazil, from 2002 to 2011, $20,590,599$ hospitalizations of older adults were held by the Unified Health System (SUS). At the time, they represented $16.11 \%$ of the population and contributed to $27.85 \%$ of hospitalizations, and to $36.47 \%$ of the resources paid for them ${ }^{(2)}$. In addition, hospitalized older adults suffer significant reduction in functionality and often receive discharge with inferior capacity compared to the functional condition of admission ${ }^{(3)}$.

This functional decline can be potentiated by hospital practices involving non-specialized health care, immobility in bed, use of psychopharmacological medication, application of urinary catheter, among other factors ${ }^{(4)}$. One can note the lack of professionals trained and with knowledge to deal with these specificities, as well as of hospitals that follow institutional and administrative practices and have at their disposal educational resources capable of improving the care towards older adults ${ }^{(5-6)}$.

Therefore, there is need for changes and innovations in healthcare paradigms, which requires creative structures, with differentiated proposals and actions in this service. Implementing effective measures of geriatric care models from evidence-based theories and models allow the improvement of such care and the decrease in hospital costs, the improvement of functional capacity and the decrease in hospitalization time, besides being a central point of intersection for an interdisciplinary health care ${ }^{(6-7)}$.

To this end, the Nurses Improving Care for Healthsystem Elders (NICHE), a US program that acts in hospitals and healthcare organizations to improve care to the older adult, created the Geriatric Institutional Assessment Profile (GIAP). This is an instrument developed from practical protocols established by experts during the expansion of the NICHE project and in the studies by Champion and Leach ${ }^{(8)}$, and Solomon et $\mathrm{al}^{(9)}$. It is used by hospitals to assess the appropriate use of treatments, the knowledge of geriatric syndromes, and the organizational attributes relevant to such health care according to information provided by nurses ${ }^{(10-11)}$.

GIAP is a self-administered, valid and reliable instrument; the Cronbach's alpha coefficient ranges from 0.6 to $0.94^{(11-12)}$. It has been used in countries as Canada, Netherlands, Singapore and Portugal; in the latter, it was translated, adapted and validated ${ }^{(13)}$. The GIAP consists of questions with demographic information, four perception subscales about the practice environment with geriatric care, six subscales directed to professional questions and one about knowledge in Geriatric Nursing ${ }^{(14)}$. In Brazil, there are no similar official instruments that promote this assessment.

Thus, a group of researchers from the School of Nursing at the Federal University of Minas Gerais (UFMG) sought, in partnership with the Rory Meyers College of Nursing at the New York University, authorization to access the GIAP, in order to enable studies that evaluate and compare hospital care to older adults and, also, to systematize knowledge, attitudes and perceptions about health professionals' best practices. This article results from a master's thesis.

\section{OBJECTIVE}

To describe the adaptation process of the GIAP to Brazilian Portuguese, as well as to establish the content and face validity.

\section{METHOD}

\section{Ethical aspects}

Before conducting this study, we obtained authorization of the NICHE coordination, managed by Dr. Barbara Bricoli, and the approval of both the Research Ethics Committee at the Federal University of Minas Gerais and the Ethics Committee of the institution where the preliminary data were collected.

\section{Study design, location, and period}

This is a methodological study that used Beaton's guidelines ${ }^{(15)}$. The process included five stages: translation, synthesis of translations, back translation, expert committee, and pre-test.

The pre-test was applied in a large hospital in the capital of Minas Gerais, Belo Horizonte, in June 2017.

\section{Sample and inclusion criteria}

Thirty-one nurses participated in the pre-test. The sample size was established according to the recommended by Beaton ${ }^{(15)}$. Inclusion criteria were: being a nurse; having clinical experience; having Portuguese as native language; and being inserted in the institution participating in specialist medical units. Nurses working in units that provided care mostly to younger adults or children as well as those in positions of nursing managers and supervisors were excluded.

\section{Study protocol}

The GIAP version provided by NICHE has 25 questions, evaluated in Likert scale of 4 points, in which higher scores indicate an environment of favorable practice and better knowledge and attitudes of nurses. This instrument consists of 133 items that analyze the characteristics of the unit/hospital and the demographic/professional characteristics of interviewees, besides three major scales. The Geriatric Nursing Knowledge/Attitudes Scale of evaluates nurses' knowledge and attitudes toward four common geriatric syndromes: pressure ulcers, incontinence, use of contentions, and sleep disorders. The Scale of Geriatric Care Environment (GCE) investigates organizational characteristics that promote or hinder the GCE. It consists of four subscales: availability of resources; provision of age-sensitive care; institutional values related to older adults and team; and continuity of care. On the other hand, the Professional Issues (PI) sub-scales examines interpersonal and coordinative aspects of professional practice, consisting of six subscales: disagreements between team/ family/patient in relation to the treatment of common geriatric 
syndromes; legal perceived vulnerability related to pressure ulcers, falls, use of restraints, hospital infection, and injuries related to sedative medications; overload caused by disruptive behaviors; disagreement of the team in relation to the treatment of common geriatric syndromes; perception of disturbing behaviors and use of geriatric services ${ }^{(16)}$.

Initially, the translation into Brazilian Portuguese was conducted by two bilingual translators ${ }^{(15)}$. The first translation (T1) was performed by a doctor in Research and Theory Development, master in Nursing, with experience in translation and adaptation of healthcare documents. He was advised on the concepts in the instrument and its purpose. The second translation (T2) was responsibility of an undergraduate in Literature and Languages - Foreign Language (UFMG), without specific knowledge in the area. Thus, two versions in Portuguese were prepared and compared. After comparison, the two translators and the researcher developed a synthesized version (T12)(15). The T12 was revised by an evaluator, doctor in Public Health and PhD in older adult's Health. He was aware of objectives of the research and had the original versions of GIAP, T1, T2 and T12. After revising the document, the evaluator considered the translations equivalent and the synthesis appropriate. The synthesis was then back translated by two translators that had English as their native language. The back translation (BT) was subjected to a revision of semantic equivalence by a doctor in Literature and Languages, specialized in translation and adaptation of instruments. Thus, the consolidated version was obtained ${ }^{(15)}$.

This version was examined by an interdisciplinary committee of judges, responsible for analyzing all versions of the instrument during the process. The objective was to contribute to the establishment of a pre-final version culturally adapted to the Brazilian context ${ }^{(15)}$. The choice of these professionals was by convenience, not random, since they were selected for being linked to the topic ${ }^{(17)}$. Inclusion criteria to form the committee were: having knowledge in the area of health care to older adults; having experience in teaching; domaining the English language; and knowing the process of cultural adaptation of instruments. Exclusion criteria were: presenting inaccurate completion of forms and/or instruments; not participating in three or more rounds of opinions.

The committee of judges consisted of four doctors and two masters in Nursing; one doctor in Gerontology and Geriatrics; one English professor, with seven years of experience; one psychologist, specialist in Gerontology; and one nurse, specialist in Geriatrics (health care and research), all with domain of English language ${ }^{(15)}$. The committee of judges totaled 10 members.

Each of them received, via e-mail, a set of documents, consisting of: letter of invitation; informed consent form (ICF); form of professional identification and characterization; instrument for evaluation of semantic, idiomatic, experimental, and conceptual equivalences of the model to be adapted; and a chart with all existing versions of GIAP (original version, $\mathrm{T} 1$, $\mathrm{T} 2$, and $\mathrm{BT} 1$ ) ${ }^{(15)}$.

The judges analyzed the material by electronic mail, and, individually, evaluated the proposed trial. After all judges answered, their suggestions for adjustments of the instrument, accompanied by the respective justifications, were gathered and forwarded to the members of the group for consideration, aiming at obtaining consensus on the trial of the equivalences evaluated. A new deadline for reply was agreed and, after five rounds of evaluation by the committee, all discrepancies were resolved, resulting in the Brazilian pre-final version of the GIAP instrument ${ }^{(15)}$.

To quantify the agreement degree between judges, each of them independently evaluated the agreement about certain aspects of the instrument and its items. In this case, the Content Validity Index (CVI) was used ${ }^{(18)}$.

The interpretation of the results was calculated by the sum of relative frequencies of responses three (I agree) and four (I completely agree), that verified the judges' agreement level in relation to the adequacy of the items evaluated. The indicative of adequacy to the original text was considered both for the evaluation of each item as for the general instrument evaluation, with CVI higher or equal to $0.8^{(17,19)}$. To calculate the general CVI, all CVI calculated separately were summed and the result was divided by the number of items. The operationalization of the rounds of opinions was conducted based on Delphi technique ${ }^{(17)}$.

Then, face validity was verified, i.e. whether the questions of the scale presented form and vocabularies appropriate to the purpose of measurement ${ }^{(20)}$. In this case, a questionnaire of 25 items was created: 11 concerning the objective, referring to purposes, goals or objectives aimed when using the GIAP; 09 concerning the structure and presentation, relating to the way of presenting guidelines, which includes its overall organization, structure, presentation strategy, consistency and formatting; and 05 concerning the relevance, referring to characteristics that evaluate the degree of signification of the material presented ${ }^{(21)}$.

As a result, the pre-final version of GIAP, used in the pre-test stage, which aims to assess the understanding, the clarity of items, and the response time of the instrument, was obtained. Participants responded to the questionnaire and, in the end, they were asked about possible doubts during its filling and the degree of difficulty in understanding the items. Data were collected individually in a restricted place and in the researcher presence. In the case of items judged insufficiently clear, nurses were asked to suggest modifications ${ }^{(15)}$. All participants signed the informed consent form.

\section{Analysis of the results}

Data related to the cross-cultural adaptation stages of the GIAP instrument for Brazil were organized in charts and analyzed descriptively. Pre-test data were stored in spreadsheets of the software Statistical Package for the Social Sciences (SPSS) version 18.0, and subjected to descriptive statistical analyses. On the other hand, the data related to analysis of content validity of the Brazilian version of GIAP were organized in the program Microsoft Excel 2010 and analyzed descriptively.

\section{RESULTS}

The two versions produced in the first stage of the crosscultural adaptation of GIAP for Brazil (T1 and T2) showed no large differences in translation. The version $\mathrm{T} 1$ (clinical translator) showed the highest technical rigor, with more reliable clinical 
equivalence and measurement of content. The version T2 (naive translator), which reflects the translator's neutrality, contemplated a language more accurate to the original version. For example, a doubt reported by the second translator was about maintaining the translation "adulto mais velho (older adult)", a term commonly used in the United States, or "idoso (elderly)", usually employed in Brazil. In the synthesized version (T12), the term "idoso (elderly)" was maintained, because it is more suited to the Brazilian reality.

For the development of the T12, the semantic construction and the clarity of words as well as their correspondence with the original version were noted. It was held by the two translators and the researcher. Then, we decided to revise this version; stage conducted by an evaluator, doctor in Public Health, with domain of the English language. He knew the objectives of the research and considered the equivalent versions and proper synthesis.

As for the back translation (BT12) stage of the version T12, people native from the USA (country of origin of GIAP) were recruited for its conduction. Afterwards, the two back-translated versions were subjected to an evaluator, doctor in Literature and Languages and $\mathrm{PhD}$ in Translation and Interpretation of Documents, with the aim of performing its synthesis, of creating the BT12, and of analyzing its equivalence with the original GIAP.

In the fourth stage of the cross-cultural adaptation, the semantic, idiomatic, experimental and conceptual equivalences of the GIAP in Brazilian Portuguese were evaluated by a committee of ten judges. Its execution happened by email, because face-to-face meetings were impossible due to geographical barriers. In the first evaluation conducted by the committee, most of the items (71.83\%) obtained agreement from the ten judges regarding the four equivalences evaluated. For the other items of the instrument, the need for modifications was noticed. The adjustments suggested by the judges for rewriting were related, mainly, to their semantic equivalence.

These suggestions, accompanied by the respective justifications, when present, were gathered and forwarded, via e-mail, to all group members, for reevaluation. After five rounds of analysis by the committee, a consensus about the equivalence of the GIAP in Brazilian Portuguese with its original version was obtained. Sequentially, the content validity evaluation of the Brazilian version of the GIAP was conducted. Results of the CVI were proven satisfactory, with general CVI of 93.9 of agreement.

Concerning the face validity, a committee of eight experts indicated consensus among the items of the scale, which were evaluated as relevant, and secured their semantic, cultural, idiomatic and conceptual coherence. All items were understood in the way they were formulated, so that questions were little modified; the general CVI was $94.0 \%$.

The adapted version was then applied in the pre-test on a sample of 31 nurses working in the hospital. Participants were characterized by being predominantly females (96.7\%), with mean age of 32 years, and average time of nursing education of six years and two months. The pre-test was held in a private location, in the presence of the researcher. The mean time for questionnaire filling was 20 minutes.

Respondents reported the ease in understanding questionnaire items. Only a few questions were considered insufficiently comprehensible, indicating the need for adjustments, as in the item "dispositivos adaptativos (por exemplo, adaptadores de espuma, alarmes de cama) [adaptive devices (for example, foam wedges, bed alarms)]", in which eight subjects reported not knowing what were "foam adapters". In the item "O quanto você se sente vulnerável com relação à responsabilidade legal sobre (How vulnerable do you feel with respect to legal liability over)", five subjects mentioned not understanding the meaning of vulnerable. On the other hand, in the item "Lesões nervosas podem resultar do uso de dispositivos de contenção (Nerve injuries can result from the use of containment devices)", one subject questioned the ambiguity in the expression "lesões nervosas (nerve injuries)"; finally, in the item "A diferença de opinião entre profissionais da equipe (entre disciplinas) sobre problemas geriátricos comuns [The difference of opinions among professionals in the team (between disciplines) on common geriatric problems]", two subjects did not understand the terms "entre disciplinas (between disciplines)".

At this moment, the researcher and the committee of experts had a meeting and, in consensus, decided to include words that made the sentences clearer: "dispositivos adaptativos (por exemplo, adaptadores de espuma - encosto conforto triângulo, almofadas, etc -, alarmes de cama) [adaptive devices (for example, foam adapters - backrest comfortable triangle, cushion, etc -, bed alarms)]" and "O quanto você se sente vulnerável ou desprotegido com relação à responsabilidade legal sobre (How vulnerable or unprotected do you feel with regard to legal liability over)". They also agreed to replace the expressions "lesões nervosas (nerve injuries)" for "lesões dos nervos (injuries of the nerves)" and "entre disciplinas (between disciplines)" for "profissionais de diferentes áreas (professionals from different areas)".

After the committee approved/defined the modifications, the Brazilian version of the GIAP was obtained for evaluation of the care provided to older adults by nurses in hospital institutions. Because it is a very extensive instrument, Chart 1 describes only the questions related to the three main scales. Questions with the same answers were presented together, despite being separate in the adapted version.

Chart 1 - Final version in Brazilian Portuguese of the Institutional Assessment Geriatric Profile instrument, Belo Horizonte, Minas Gerais, Brazil

Geriatric Institutional Assessment Profile (Brazilian version)

- As regards the hospital you work in, how satisfied are you with the following:

\begin{tabular}{|c|c|c|c|c|c|c|}
\hline Individualized care provided by staff. & LU & $\mathrm{U}$ & LS & $\mathrm{S}$ & VS & DNA \\
\hline Elderly patients receiving necessary care. & LU & $\mathrm{U}$ & LS & $\mathrm{S}$ & VS & DNA \\
\hline The way the team addresses issues on geriatric care. & LU & U & LS & $\mathrm{S}$ & VS & DNA \\
\hline The team's familiarity with the effects of aging on treatment. & LU & $\mathrm{U}$ & LS & $\mathrm{S}$ & VS & DNA \\
\hline Aging being considered as a factor in planning and evaluation. & LU & $\mathrm{U}$ & LS & $\mathrm{S}$ & VS & DNA \\
\hline
\end{tabular}


Chart 1

\begin{tabular}{|c|c|c|c|c|c|c|}
\hline Older adult patients receiving the information they need to make decisions about their care and treatment. & LU & U & LS & $\mathrm{S}$ & VS & DNA \\
\hline Families receiving the information and support they need to help seniors in their families. & LU & $\mathrm{U}$ & LS & $\mathrm{S}$ & VS & DNA \\
\hline Staff obtaining the information and data from patients' previous hospitalization. & LU & u & LS & $\mathrm{S}$ & VS & DNA \\
\hline Continuous care between your institution and different health services. & LU & $U$ & LS & $\mathrm{S}$ & VS & DNA \\
\hline Adequate continuity between all hospital departments. & LU & $\mathrm{U}$ & LS & $\mathrm{S}$ & VS & DNA \\
\hline
\end{tabular}

- When making decisions elderly care, the following obstacles are encountered. To what extent does each one of them interfere with the care in your hospital?

Lack of knowledge/familiarity about care for the elderly.

Lack of (or inadequate) written geriatric policies and procedures.

Differences of opinion between professionals (between sectors) about common geriatric problems.

Lack of specialized services for the elderly (such as oral care, podiatry).

Lack of special equipment (e.g. raised toilet seats/special mattresses).

Exclusion of nurses from the decisions of geriatric care.

Economic pressure to limit the treatment or duration of stay.

Lack of staff or time limitations.

Communication difficulties with seniors and their families.

Exclusion of the elderly from their own care decisions.

Confusion about who is responsible for the appropriate decisions.

\begin{tabular}{|c|c|c|c|c|c|}
\hline DNI & $\mathrm{L}$ & $\mathrm{I}$ & $\mathrm{V}$ & $\mathrm{El}$ & DNA \\
\hline DNI & $\mathrm{L}$ & $\mathrm{I}$ & $\mathrm{V}$ & $\mathrm{El}$ & DNA \\
\hline DNI & $\mathrm{L}$ & $\mathrm{I}$ & $\mathrm{V}$ & $\mathrm{El}$ & DNA \\
\hline DNI & $\mathrm{L}$ & $\mathrm{I}$ & $\mathrm{V}$ & $\mathrm{El}$ & DNA \\
\hline DNI & $\mathrm{L}$ & $\mathrm{I}$ & $\mathrm{V}$ & $\mathrm{El}$ & DNA \\
\hline DNI & $\mathrm{L}$ & $\mathrm{I}$ & $\mathrm{V}$ & $\mathrm{El}$ & DNA \\
\hline DNI & $\mathrm{L}$ & $\mathrm{I}$ & $\mathrm{V}$ & $\mathrm{El}$ & DNA \\
\hline DNI & $\mathrm{L}$ & $\mathrm{I}$ & $\mathrm{V}$ & $\mathrm{El}$ & DNA \\
\hline DNI & $\mathrm{L}$ & $\mathrm{I}$ & $\mathrm{V}$ & $\mathrm{El}$ & DNA \\
\hline DNI & $\mathrm{L}$ & $\mathrm{I}$ & $\mathrm{V}$ & $\mathrm{El}$ & DNA \\
\hline DNI & $\mathrm{L}$ & $\mathrm{I}$ & $\mathrm{V}$ & El & DNA \\
\hline
\end{tabular}

- How often do you use these geriatric services?

Specialized nurse in geriatrics or geriatric nursing.

Geriatrician.

Geriatric social worker.

Geriatric psychologists or psychiatrists.

Patient transfers and internal geriatric services.

Geriatric texts and magazines.

Geriatric, conferences/workshops, regional or national.

- How vulnerable do you feel with respect to legal responsibility for:

Development of pressure ulcers in the elderly.

Elderly patients falling.

Accusations of illegal restraints.

Injuries resulting from use of restraining devices.

Nosocomial infection from the use of a catheter.

Lesions resulting from use of sedative medication.

- Some older adults may exhibit disruptive behaviour. How often do elderly patients under your care:

- To what extent does it disturb or bother you when elderly patients:

[F - frequent (5 or more times per week); S - Sometimes (1-4 times a week); N - Never; DNA - Does Not Apply]

Get picky/demanding.

Get argumentative/critical.

Become uncooperative.

Request guarantees or reaffirmation/attention / assistance/support in decision-making

Stay awake at night.

Wander about during the day.

Get confused or agitated.

- How strongly do you agree or disagree with the following statements about your hospital:

Doctors and administrators work together to resolve problems for elderly patients.

You are allowed to disagree with your supervisor about the care of seniors.

The employee's participation is sought in setting policies and guidelines for geriatric care.

Elderly patients are always treated with respect.

Qualified employees are involved in the decisions about geriatric care.

\begin{tabular}{|c|c|c|c|c|c|}
\hline DL & W & M & LM & R & NA \\
\hline DL & W & M & LM & R & NA \\
\hline DL & W & M & LM & R & NA \\
\hline DL & W & M & LM & R & NA \\
\hline DL & W & M & LM & R & NA \\
\hline DL & W & M & LM & R & NA \\
\hline DL & W & M & LM & R & NA \\
\hline
\end{tabular}

\begin{tabular}{|c|c|c|c|c|c|}
\hline VV & V & LV & NVV & NV & DNA \\
\hline VV & V & LV & NVV & NV & DNA \\
\hline VV & V & LV & NVV & NV & DNA \\
\hline VV & V & LV & NVV & NV & DNA \\
\hline VV & V & LV & NVV & NV & DNA \\
\hline VV & V & LV & NVV & NV & DNA \\
\hline
\end{tabular}


Chart 1 (concluded)

\begin{tabular}{|c|c|c|c|c|c|c|}
\hline Personal growth is encouraged. & SA & A & NAND & $\mathrm{D}$ & SD & DNA \\
\hline Rights of elderly patients are protected. & SA & A & NAND & $\mathrm{D}$ & SD & DNA \\
\hline \multicolumn{7}{|l|}{ - How strongly you agree or disagree with the following statements: } \\
\hline The majority of pressure ulcers are preventable. & & SA & A & NAND & $\mathrm{D}$ & SD \\
\hline Pressure ulcers occur in about half of elderly hospital patients. & & SA & A & NAND & $\mathrm{D}$ & SD \\
\hline It is almost always possible to avoid skin lesions. & & SA & A & NAND & $\mathrm{D}$ & SD \\
\hline The heels are one of the regions most susceptible to skin breakdown in bedridden elderly patients. & & SA & A & NAND & $\mathrm{D}$ & SD \\
\hline Pressure ulcers can lead to osteomyelitis. & & SA & A & NAND & $\mathrm{D}$ & SD \\
\hline Regular massage of prominent bones can help reduce skin lesions. & & SA & A & NAND & $\mathrm{D}$ & SD \\
\hline The hospital appreciates the time spent with prevention of pressure ulcers. & & SA & A & NAND & $\mathrm{D}$ & SD \\
\hline I don't have time to do daily skin evaluations of my elderly patients. & & SA & A & NAND & $\mathrm{D}$ & SD \\
\hline Adequate nutrition is the most essential element to the prevention of skin lesions. & & SA & A & NAND & $\mathrm{D}$ & SD \\
\hline Sleeping problems in elderly hospital patients contribute negatively to the hospital's results. & & SA & A & NAND & $\mathrm{D}$ & SD \\
\hline Sedatives get rid of hallucinations and agitation in elderly patients with sleeping disorders. & & SA & A & NAND & $\mathrm{D}$ & SD \\
\hline The majority of sleeping problems in elderly patients requires the use of sedatives. & & SA & A & NAND & $\mathrm{D}$ & SD \\
\hline Sleeping problems should always be treated aggressively. & & SA & A & NAND & $\mathrm{D}$ & SD \\
\hline We do a good job identifying and preventing sleeping disorders. & & SA & A & NAND & $\mathrm{D}$ & SD \\
\hline The time spent in prevention of sleeping problems is valued in this hospital. & & SA & A & NAND & $\mathrm{D}$ & SD \\
\hline Without the aid of sedatives, I don't have time to help prevent sleeping problems. & & SA & A & NAND & $\mathrm{D}$ & SD \\
\hline The prevalence of incontinence in elderly patients is close to 20 percent. & & SA & A & NAND & $\mathrm{D}$ & SD \\
\hline Problems with urinary continence are a normal part of aging. & & SA & A & NAND & $\mathrm{D}$ & SD \\
\hline Kegel exercises are good for all types of incontinence. & & SA & A & NAND & $\mathrm{D}$ & SD \\
\hline Constipation can lead to urinary incontinence. & & SA & A & NAND & $\mathrm{D}$ & SD \\
\hline The hospital values the time spent managing urinary continence without the use of catheters or incontinence. & & SA & A & NAND & $\mathrm{D}$ & SD \\
\hline $\begin{array}{l}\text { I try to avoid the use of long-term indwelling catheters in elderly patients, even if that means they } \\
\text { occasionally wet themselves. }\end{array}$ & & SA & A & NAND & $\mathrm{D}$ & SD \\
\hline
\end{tabular}

- How strongly you agree or disagree with the following statements:

We use adult incontinence clothing at night for most of our elderly patients

Urinary catheters are adequate in incontinence treatments as long as they are discontinued after 10 days

Reducing the use of catheters creates significant demands of the team's time

Permanent catheters are the principal cause of sepsis in older hospitalized adults.

Bed or chair restraints bring more security to confused elderly patients.

Nerve damage may result from the use of restraint devices.

Utilizing restraints often contributes to confusion of elderly patients.

I check on elderly patients at least once an hour.

When the use of mechanical restraints is decreased, the use of sedative drugs increases

In this hospital, all reasonable alternatives are attempted before restraining elderly patients.

Doctors need better guidelines to help determine what is appropriate care for the elderly.

Many elderly patients prefer to let their caretaker make the decision about the what the best treatment is.

My colleagues value my opinion about adequate care of elderly patients.

\begin{tabular}{|c|c|c|c|c|}
\hline SA & A & NAND & D & SD \\
\hline SA & A & NAND & D & SD \\
\hline SA & A & NAND & D & SD \\
\hline SA & A & NAND & D & SD \\
\hline SA & A & NAND & D & SD \\
\hline SA & A & NAND & D & SD \\
\hline SA & A & NAND & D & SD \\
\hline SA & A & NAND & D & SD \\
\hline SA & A & NAND & D & SD \\
\hline SA & A & NAND & D & SD \\
\hline SA & A & NAND & D & SD \\
\hline SA & A & NAND & D & SD \\
\hline SA & A & NAND & D & SD \\
\hline
\end{tabular}

Note: LU - Little Unsatisfied; U - Unsatisfied; LS - Little Satisfied; S - Satisfied; VS - Very Satisfied; DNA - Does not apply; DNI - Does not interfere; L - Little; I Interferes; V - Very; EI - Expressively interferes; DL - Daily; W-Weekly; M - Monthly; LM - Less than monthly; R-Rarely; NA - Not available; VV-Very vulnerable; V-Vulnerable; LV - Little vulnerable; NVV-Not very vulnerable; NV-Not vulnerable; SA - Strongly agree; A - Agree; NAND - Neither agree nor disagree; D - Disagree; SD - Strongly disagree.

\section{DISCUSSION}

The adaptation of a measuring instrument is not a simple or linear process, because different cultures present both linguistic and cultural divergences evident in the translation and back translation processes. The participation of bilingual translators, with knowledge in adaptation and linguistic processes, minimizes translation errors and provides more quality if they can identify and correct incomprehensible, unacceptable, incomplete, and irrelevant translated items ${ }^{(22)}$.

The Brazilian version of the GIAP had a good agreement among judges. Sections with translation errors, linguistic and cultural inadequacies were prioritized. The strategy of using an interdisciplinary committee of experts favors the identification 
and correction of these problems, besides ensuring greater semantic, conceptual, and technical equivalence of the instrument adapted ${ }^{(17)}$. Questions related to the characterization of the population studied raised important discussions among judges.

The term nurse practitioner, for example, refers to a professional that specializes in health care. However, nurse practitioners must complete a master or doctorate's program and have an advanced clinical training beyond their initial preparation in the professional nursing degree ${ }^{(23)}$. In Brazil, there are specialist nurses, but not with this educational profile. Thus, to ensure cultural equivalence, the term "Enfermeiro especialista (specialist nurse)" was maintained, as agreed by $100 \%$ of the panelists in the fourth round.

The term staffeducator also diverged opinions. The expression considered most appropriate by experts was" Profissional responsável pela educação continuada (Professional responsible for continuing education)", because it portrays a function performed by nurses and maintains the cultural and conceptual equivalence This decision corroborates the guidelines of the Pan American Health Organization, which recommends one professional nurse for the post of coordinator and responsible for continuing education ${ }^{(24)}$.

The expressions licensed practical nurse/licensed vocational nurse ( $L P N / L V N$ ) were adapted to the Brazilian context as "Técnico em enfermagem (nurse technician)", because there is no equivalent training in the country. After all, the term refers to a level of education with shorter duration, aimed at lower-complexity care in relation to the activities performed by the registered nurse (RN) in the United States, such as what happens with the technical nursing education in relation to a bachelor's degree in Brazil ${ }^{(25)}$.

Three issues evaluated the frequency of use of some treatments for common geriatric syndromes and the presence of disagreement among employees, patients and families in this respect. The term incontinence pads, which refers to the use of plasters, and incontinence garment, which refers to materials used in the treatment of incontinence, caused discussions. The experts chose the expressions "absorventes para incontinêncial dispositivos para incontinência (absorbents for incontinence/ devices for incontinence)" to replace the first expression and "vestimentas para incontinência (ex: fralda, roupa íntima para a incontinência) [clothing for incontinence (ex: diapers, underwear for incontinence)]" for incontinence garment. In a study about the facing of urinary incontinence by women without prospects of access to surgical treatment, the terms "absorventes (absorbents)" or "dispositivos (devices)" were used as palliative and non-invasive measures in the control of incontinence ${ }^{(26)}$.

Furthermore, the result obtained by the CVI calculation (0.94) showed that the Brazilian version of the GIAP instrument has valid content ${ }^{(19)}$ for evaluation of care provided by nurses for hospitalized older adults in this country.
In the pre-test of the instrument, conducted with 31 subjects, the good acceptance and the respondents' ease of understanding were noticed, except for four items. In one of them, we identified the lack of knowledge in foam adapters, resources commonly used in prevention or reduction of functional losses by occupational therapists, who use several techniques as technological devices and facilitated forms of conducting activities to increase comfort and adapt the bed for changes in decubitus positions ${ }^{(27)}$. However, this is a marginalized field inside the hospital, which can justify nurses' incomprehension. Besides, when this work occurs, it commonly is performed by professionals from another area.

In another item, we opted for the replacement of the term "entre disciplinas (between disciplines)" to "profissionais de diferentes áreas (professionals from different areas)". Interdisciplinarity is conceptualized by the degree of integration between disciplines and intensity of exchanges between experts. The work of a multiprofessional team can express the possibility of integrating scientific disciplines, because they are based on and operationalized in technologies that interfere with the daily life ${ }^{(28)}$.

Several questions caused discussions among experts during the adaptation process, which refined the instrument and allowed a higher quality of adaptation, in an interactive and systematic process.

\section{Study limitations}

We consider that new studies must be conducted to obtain validity and reliability evidence of GIAP through tests on representative samples, composed of different regional groups. This limitation will be resolved through a continuous evaluation process of its psychometric properties, which is already being held by the authors.

\section{Contributions to the nursing field}

GIAP is available in English, and the Brazilian Portuguese version will expand its use in the Latin American context. With the purpose of working with well defined and validated construct for specific country and culture, this study will allow future evaluations of the healthcare process to older adults in order to improve the quality of care. In addition, it will allow the recognition of differences and similarities between nurses' perceptions in different Brazilian contexts.

\section{CONCLUSION}

The Brazilian version of the GIAP achieved the equivalence criteria between the original and the translated questionnaire. It provided support for content and face validation. The questionnaire, therefore, can assess nurses' environment of geriatric practice and knowledge, when applied to the Brazilian context.

\section{REFERENCES}

1. Pilger C, Menon MU, Mathias TAF. Health services use among elderly people living in the community. Rev Esc Enferm USP [Internet]. 2013 [cited 2017 Aug 28];47(1):213-20. Available from: http://www.scielo.br/pdf/reeusp/v47n1/en_a27v47n1.pdf

2. Silveira RE, Santos AS, Sousa MC, Monteiro TSA. Expenses related to hospital admissions for the elderly in Brazil: perspectives of a decade. Einstein (São Paulo) [Internet]. 2013 [cited 2017 Aug 28];11(4):514-20. Available from: http://www.scielo.br/pdf/eins/v11n4/en_19.pdf 
3. Admi H, Shadmi E, Baruch H, Zisberg A. From Research to Reality: Minimizing the Effects of Hospitalization on Older Adults. Rambam Maimonides Med J [Internet]. 2015 [cited 2017 Aug 28];6 (2):e0017. Available from: https://www.ncbi.nlm.nih.gov/pmc/articles/ PMC4422456/pdf/rmmj-6-2-e0017.pdf

4. Pereira EEB, Souza ABF, Carneiro SR, Sarges ESNF. Funcionalidade global de idosos hospitalizados. Rev Bras Geriatr Gerontol [Internet]. 2014 [cited 2017 Aug 28];17(1):165-76. Available from: http://www.scielo.br/pdf/rbgg/v17n1/1809-9823-rbgg-17-01-00165.pdf

5. Both JE, Leite MT, Hildebrandt LM, Beuter M, Muller LA, Linck CL. Qualification of the nursing team by means of convergent-care research: contributions to the care of the hospitalized elderly person. Esc Anna Nery [Internet]. 2014 [cited 2017 Aug 28];18(3):486-495. Available from: http://www.scielo.br/pdf/ean/v18n3/en_1414-8145-ean-18-03-0486.pdf

6. Tavares JPA, Silva AL. Cuidado de enfermagem geriátrica: um projecto emergente. Revista Transdisciplinar de Gerontologia [Internet]. 2011 [cited 2017 Aug 28];4(2):5-15. Available from: http://files.rtgerontologia.webnode.pt/200000065-282ea29288/RTG2.pdf

7. Kim H, Capezuti E, Boltz M, Fairchild S. The nursing practice environment and nurse-perceived quality of geriatric care in hospitals. West $J$ Nurs Res [Internet]. 2009 [cited 2017 Aug 28];31(4):480-95. Available from: http://citeseerx.ist.psu.edu/viewdoc/download?doi=10.1.1.904.8 087\&rep=rep $1 \&$ type $=$ pdf

8. Champion VL, Leach A. Variables related to research utilization in nursing: an empirical investigation. J Adv Nurs. 1989;14(9):705-10.

9. Solomon MZ, O'Donnell L, Jennings B, Guilfoy V, Wolf SM, Nolan K, et al. Decisions near the end of life: professional views on life sustaining treatments. Am J Public Health. 1993; 83(1):14-23.

10. Capezuti E, Boltz M, Cline D, Dickson VV, Rosenberg MC, Wagner L, et al. Nurses Improving Care for Healthsystem Elders: a model for optimising the geriatric nursing practice environment. J Clin Nurs [Internet]. 2012 [cited 2017 Aug 28];21(21-22):3117-25. Available from: https://www.ncbi.nlm.nih.gov/pmc/articles/PMC3532620/pdf/jocn0021-3117.pdf

11. Abraham IL, Bottrell MM, Dash KR, Fulmer TT, Mezey MD, O'Donnell L, et al. Profiling care and benchmarking best practice in care of hospitalized elderly: the Geriatric Institutional Assessment Profile. Nurs Clin North Am. 1999;34(1):237-55.

12. Boltz M, Capezuti E, Kim H, Fairchild S, Secic M. Factor structure of the geriatric institutional assessment profile's professional issues scales. Res Gerontol Nurs [Internet]. 2010 [cited 2017 Aug 28];3(2):126-34. Available from: http://web.a-ebscohost-com.ez27.periodicos.capes.gov. br/ehost/pdfviewer/pdfviewer?vid=1\&sid=f785fa30-8f9b-4c13-998c-9d4670747388\%40sessionmgr4009

13. Tavares JP, Silva AL, Sá-Couto P, Boltz M, Capezuti E. Validation of Geriatric Care Environment Scale in Portuguese nurses. Curr Gerontol Geriatr Res [Internet]. 2013 [cited 2018 Sep 06];2013:9. Available from: http://dx.doi.org/10.1155/2013/426596

14. Fulmer T, Mezey M, Bottrell M, Abraham I, Sazant J, Grossman S et al. Nurses Improving Care for Healthsystem Elders (NICHE): using outcomes and benchmarks for evidenced-based practice. Geriatr Nurs [Internet]. 2002 [cited 2017 Aug 28];23(3):121-7. Available from: http://www.gnjournal.com/article/S0197-4572(02)00001-0/fulltext

15. Beaton DE, Bombardier C, Guillemin F, Ferraz MB. Guidelines for the process of cross cultural adaptation of self-report measures. Spine [Internet]. 2000 [cited 2017 Aug 28];25(24):3186-91. Available from: https://www.researchgate.net/ publication/12203631_Guidelines_for_the_Process_of_Cross-Cultural_Adaption_of_Self-Report_Measures

16. Tavares JPA, Silva AL, Sá-Couto P, Boltz M, Capezuti E. Nurse perception of care of hospitalized older adults: a comparative study between northern and central regions of Portugal. Rev Latino-Am Enfermagem [Internet]. 2017 [cited 2017 Dec 05];25:e2757. Available from: http:// www.scielo.br/pdf/rlae/v25/0104-1169-rlae-25-e2757.pdf

17. Scarparo AF, Laus AM, Azevedo ALCS, Freitas MRI, Gabriel CS, Chaves LDP. Reflexões sobre a técnica Delphi em pesquisa na enfermagem. Rev Rene [Internet]. 2012 [cited 2017 Aug 28];13(1):242-51. Available from: https://www.researchgate.net/ publication/281497981_Reflexoes_sobre_o_uso_da_tecnica_Delphi_em_pesquisas_na_enfermagem

18. Hyrkäs K, Appelqvist-Schmidlechner K, Oksa L. Validating an instrument for clinical supervision using an expert panel. Int J Nurs Stud [Internet]. 2003[cited 2018 Sep 06];40(6):619-25. Available from: https://www.ncbi.nlm.nih.gov/pubmed/12834927

19. Polit DF, Beck CT. The content validity index: are you sure you know what's being reported? critique and recommendations. Res Nurs Health [Internet]. 2006 [cited 2017 Dec 04];29(5):489-97. Available from: http://www.ncbi.nlm.nih.gov/pubmed/16977646

20. Tomaschewski-Barlem JG, Lunardi VL, Barlem ELD, Silveira RS da, Dalmolin GL, Ramos AM. Cross-cultural adaptation and validation of the Protective Nursing Advocacy Scale for Brazilian nurses. Rev Latino-Am Enfermagem [Internet]. 2015 [cited 2017 Aug 24];23(4):669-76. Available from: http://www.scielo.br/pdf/rlae/v23n4/0104-1169-rlae-23-04-00669.pdf

21. Haynes SN, Richard DCS, Kubany ES. Content validity in psychological assessment: a functional approach to concepts and methods. Psychol Assess [Internet].1995 [cited 2017 Dec 5];7(3):238-47. Available from: http://citeseerx.ist.psu.edu/viewdoc/download?doi=10.1.1.452.5453\& rep=rep $1 \&$ type $=$ pdf

22. van Ommeren M, Sharma B, Thapa S, Makaju R, Prasain D, Bhattarai R, et al. Preparing instruments for transcultural research: use of the Translation Monitoring Form with Nepali-Speaking Bhutanese Refugees. Transcult. Psychiatry [Internet]. 1999 [cited 2017 Aug 28];36:285301. Available from: http://journals.sagepub.com.ez27.periodicos.capes.gov.br/doi/pdf/10.1177/136346159903600304

23. American Association of Nurse Practitioners. What's an NP? 2017. Available from: https://www.aanp.org/all-about-nps/ what-is-an-np\#license-and-practice-locations

24. Sade PMC, Peres AM, Pedroso JVM, Larocca LM. Núcleo de enfermeiros de educação permanente do Paraná: trajetória e contribuições. Cogitare Enferm [Internet]. 2016 [cited2017 Aug 28];21(2):01-09. Available from: http://docs.bvsalud.org/biblioref/2016/07/641/44335-178202-1-pb.pdf 
25. National League for Nursing NLN Board of Governors. A vision for recognition of the role of Licensed Practical/Vocational Nurses in Advancing the Nation's Health [Internet]. 2014 [cited 2017 Aug 28]. Available from: http://www.nln.org/docs/default-source/about/nlnvision-series-\%28position-statements\%29/nlnvision_7.pdf?sfvrsn=4

26. Delarmelindo RCA, Parada CMGL, Rodrigues RAP, Bocchi SCM. Women's strategies for coping with urinary incontinence. Rev Esc Enferm USP [Internet]. 2013 [cited 2017 Aug 29];47(2):296-303. Available from: http://www.scielo.br/pdf/reeusp/v47n2/en_04.pdf

27. Almeida MHM, Cruz GA. Intervenções de terapeutas ocupacionais junto a idosos com doença de Parkinson. Rev Ter Ocup Univ [Internet]. 2009[cited 2018 Jul 18];20(1):29-35. Available from: http://www.revistas.usp.br/rto/article/view/14053

28. Costa RP. Interdisciplinaridade e equipes de saúde: concepções. Mental [Internet]. 2007[cited 2018 Jul 18];5(8):107-24. Available from: http:// pepsic.bvsalud.org/pdf/mental/v5n8/v5n8a08.pdf 